
and Allied Sciences (IJBPAS)

'A Bridge Betuen Caboratory and QRendo'

WWW.ijbpas.com

\title{
REVIEW ON PYRAZOLINE DERIVATIVES HAVING ANTIDEPRESSANT PROPERTY
}

\section{MANDAL SK ${ }^{1 *}$, PATRA $M^{2^{*}}, \operatorname{KAPOOR} \mathrm{B}^{3}$, BOSE $^{4}, \operatorname{KUMAR~A}^{5}$ AND RAJ A ${ }^{6}$}

1: Department of Pharmaceutical Chemistry, Dr. B. C. Roy College of Pharmacy and Allied Health Sciences, Durgapur, West Bengal 713206, India

2: Department of Pharmaceutical Chemistry, Bengal School of Technology, Sugandha, Delhi Road, Chuchura, Hooghly, West Bengal-712102, India

3: Department of Pharmaceutical Chemistry, School of Pharmaceutical Sciences, Lovely

Professional University, Phagwara, Punjab, India

4: Department of Pharmacognosy, Bengal School of Technology, Sugandha, Delhi Road, Chuchura, Hooghly, West Bengal-712102, India

5: Department of Pharmaceutical Chemistry, Sachchidanand Sinha College, Aurangabad 824101, Bihar, India

6: Department of Pharmacology, Sachchidanand Sinha College, Aurangabad -824101, Bihar, India

Corresponding Author': Dr. Sudip Kumar Mandal; E Mail: gotosudip79@gmail.com;

Ph.No.: +91-8670192100

Corresponding Author²: Maunab Patra; E Mail: maunab patra@rediffmail.com; Ph.

No.: +91-9831472814

Received 25 ${ }^{\text {th }}$ March 2020; Revised $20^{\text {th }}$ April 2020; Accepted $15^{\text {th }}$ July 2020; Available online $1^{\text {st }}$ Jan. 2021

https://doi.org/10.31032/IJBPAS/2021/10.1.5305

\section{ABSTRACT}

Depression is potentially life-threatening disorder which is affecting people worldwide. It is not limited by age and is a curse to the society as it causes severe distress and, if left untreated, can even cause death. There are different chemical moieties showing antidepressant properties such as benzodiazepines, hydrazones, imidazoles, indoles, piperazines, piperidines, pyrazolines, pyrimidines, pyrrolidones, quinazolines, quinolines, 
thiadiazoles and triazoles. Among all these chemical moieties, the pyrazolines possess a broad spectrum of pharmacological activities such as analgesic, anti-pyretic, antiinflammatory, insecticide, uricosuric, anti-epileptic, anti-depressant, anti-microbial, anticancer, anti-tubercular, hypotensive, anti-nociceptive, and anti-oxidant activity. Recently synthesized antidepressants having pyrazoline moiety has been the highlight of this present review. It has been found that most of the substitutions are taking place in the $1^{\text {st }}, 2^{\text {nd }}, 3^{\text {rd }}$ and $5^{\text {th }}$ position to exhibit antidepressant property in the form of MAO inhibition. The substitution in the $4^{\text {th }}$ position has found to decrease the activity, but fused phenyl ring in the $3^{\text {rd }}$ and $4^{\text {th }}$ position exhibited acute potency. Marked response is observed when $3^{\text {rd }}$ and $5^{\text {th }}$ positions encounter substitutes or non substituted six membered aromatic rings attachment along with substituted thioacetamide in the $1^{\text {st }}$ position. These conclusions were drawn on the basis of results obtained from Despair Swim Test.

\section{Keywords: Pyrazolines, Antidepressant property, MAO inhibition}

\section{INTRODUCTION}

Depression is a major heterogeneous mood disorder [1]. Chronic and acute depression interfere severely in one's healthy life, consequently causing a discontinuation in the normal physical, mental, and social well-being of the affected person and the family from which he belongs, drives him even to commit suicide [2]. It is a state of low mood [3]. Patients suffering from depression may feel sad, anxious, empty, hopeless, worried, helpless, worthless, guilty, irritable, or restless, loss of interest in activities that were once pleasurable, loss of appetite, overreaction, loss of concentration, memory and making in correct decisions [4]. Life events that may precipitate depressed mood include personal conflicts or disputes with family members or friends, bereavement, losing a job or income, divorce, stress, retirement, menopause, social isolation, and social rejection [2]. Depression can be a consequent result of fluctuating circadian rhythm [6].

Monoamine Oxidase was first discovered seventy years ago. This enzyme naturally exists in two isoforms: MAO-A and MAO-B. MAO-A degrades to 5hydroxytryptamine (5-HT) and noradrenaline (NA) but MAO-B turns to phenyl ethylamine and secondary amine. Clorgyline and deprenylare well know drugs used as MAO-A and MAO-B inhibitors respectively. Inhibitory activities to these receptors are irreversible [7].

There are different chemical moieties showing anti-depressant properties such as, benzodiazepines [8], hydrazones 
[9], imidazoles, indoles, piperazines, piperidines, pyrazolines, pyrimidines, pyrrolidones [10], quinazolines [11], quinolines, thiadiazoles and triazoles. Among them pyrazolines possess a wide range of pharmacological activities such as anticonvulsant, anti-psychotic, antiarrhythmic, anti-microbial, cytotoxic, antioxidant and anti-malarial activity [12].

Chemically pyrazolines can be characterized by a five-membered heterocyclic ring structure containing two nitrogen atoms in it along with a double bond. They are classified as an important class of heterocyclic compounds due to their pronounced biological and pharmacological activities [13].

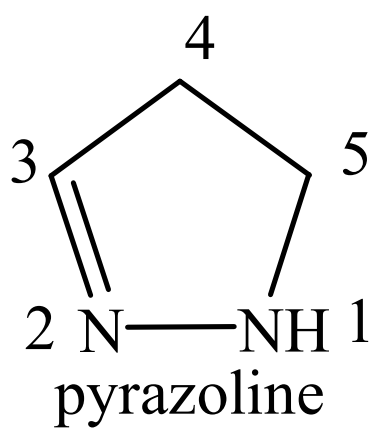

The present review is about recently synthesized pyrazolines possessing antidepressant activity.

\section{ANTIDEPRESSANT ACTIVITY OF PYRAZOLINES}

Ozmedir et al. designed and synthesized a set of derivatives of 3-(2Thienyl) pyrazolines, out of which the given compounds were found to be the most potent forms as conclusions received from duration of immobility tests [14]. These potent compounds $\mathbf{1 a}$ and $\mathbf{1 b}$ have duration of immobility time of $43 \pm 15.3$ seconds and 48. \pm 18.9 seconds respectively whereas standard drug Tranylcypromine sulfate showed duration of immobility time of $57 \pm 11.6$ seconds.

Kaplancikli et al synthesized a set of derivatives of 3-Thiophen-2-yl-4,5dihydro-pyrazole-1-carbaldehyde [15]. Among them, marked response with duration of immobility time of $33.3 \pm 3.9$ seconds was observed for the derivative 2 and in comparison, the standard drug, Fluoxetine experimentally found to have $67.6 \pm 4.1$ seconds as duration of immobility time.

Ruhoglu et al. synthesized 1,3,5Trisubstituted pyrazolines that exhibited antidepressant property [16]. Derivatives 3a and $\mathbf{3 b}$ reported to have duration of immobility time of $4.57 \pm 2.92$ seconds and $14.78 \pm 22.01$ seconds respectively whereas standard drug Tranylcypromine sulfate has duration of immobility time of $49.71 \pm 2.11$ seconds.

Again Iyidogan et al. further investigated these1,3,5-Trisubstituted pyrazolines and came across synthesizing another new set of derivatives [17]. Most of the derivatives possess low potency but among them thederivatives $\mathbf{4 a}$ and $\mathbf{4 b}$ with duration of immobility time of $7 \pm 3.10$ seconds and 
$14 \pm 8.2$ seconds against the standard drug immobility time of $24 \pm 6.6$ seconds.

Tranylcypromine sulfate with duration of

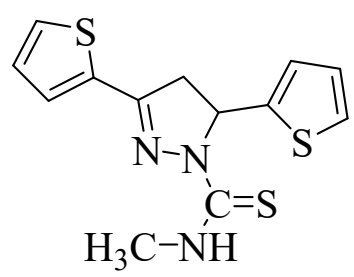

$1 \mathbf{a}$<smiles>NC(=S)N1N=C(c2cccs2)CC1c1cccs1</smiles>

$\mathrm{C}_{6} \mathrm{H}_{5}-\mathrm{NH}$<smiles>Nc1nnc(CCCc2ccc(O)cc2)n1SCC(=O)N1N=C(c2cccs2)CC1c1ccccc1</smiles>

2<smiles>CCCCCN(C)C1CC(c2ccccc2)=NN1c1ccco1</smiles>

3a<smiles>NC(=O)N1N=C(c2ccccc2)CC1c1cccs1</smiles>

3b<smiles></smiles>

4a<smiles></smiles>

$4 \mathbf{b}$<smiles>CCCCCCOc1ccc(C2CC(c3ccc(OCC=C(C)C)cc3O)=NN2C(C)=O)cc1</smiles>

5

Fioravanti et al synthesized a set of 1-\{3- thiocarbamoyl-3,5-di(hetero)aryl-4,5-

[2-Hydroxy-4-(3-methyl-but-2-enyloxy)phenyl]-5-phenyl-4,5-dihydro-pyrazol-1yl\}-ethanone derivativesusing molecular modeling [18]. The mentioned compound 5 showed the best potency as hMAO-B inhibitor with $\mathrm{K}_{\mathrm{i}}$ value $(\mu \mathrm{M}) 6.76$ and the standard drug Clorgyline having $\mathrm{K}_{\mathrm{i}}$ value $(\mu \mathrm{M}) 8.35$.

Later molecular modeling became the basic approach for designing antidepressants and Fioravanti et al made a further progress by synthesizing another new set of anti-depressants (N1-
dihydro-(1H)-pyrazoles) [19]. Marked response was reported for the mentioned derivatives $\mathbf{6 a}$ and $\mathbf{6 b}$ with $\mathrm{IC}_{50}(\mu \mathrm{M})$ for MAO-A and MAO-B of 6.70 and 6.82 respectively. It was found that the standard drug Moclobemide has given $\mathrm{IC}_{50}(\mu \mathrm{M})$ for MAO-A and MAO-B of 4.94 and 2.00 respectively.

Jayaprakash et al. took an initiative to synthesize pyrazoline based mycobactin analogues [20]. Maximum MAOAinhibitory activity was found for derivative 7 with $\mathrm{IC}_{50}(\mu \mathrm{M})$ of $2.84 \pm 0.19$ 
which may have therapeutic utility in Alzheimer disease. The standard drug Clorgyline produced $\mathrm{IC}_{50}(\mu \mathrm{M})$ for MAOA, of $2.05 \pm 0.19$.

Karuppasamy et al. synthesized 3,4Diaryl pyrazolines analogues and evaluated for their MAO inhibitory activity [21]. The compounds were found reversible and selective towards MAO-A with selectivity index in magnitude of $10^{3}-10^{5}$. The mentioned derivative 8 with $K_{i}$ value $(\mu \mathrm{M})$ $150.10 \pm 10.05$ (MAO-A) was found to have the maximum potency against the standard drug Moclobemide showing $\mathrm{K}_{\mathrm{i}}$ value $(\mu \mathrm{M})$ of $5.53 \pm 0.27$.

A novel series of 2-thiocarbamoyl2,3,4,5,6,7-hexahydro- $1 H$-indazole and 2substituted thiocarbamoyl-3,3a,4,5,6,7hexahydro- $2 H$-indazole were synthesized by Kelekci et al. and investigated their MAO-A \& B inhibitory activity [22]. The mentioned derivatives 9a and $9 \mathbf{b}$ with $\mathrm{K}_{\mathrm{i}}$ values $(\mu \mathrm{M}) 0.96 \pm 0.01$ and $0.90 \pm 0.01$ both showing MAO-B inhibitory activity, were found to have the optimized potency whereas the standard drug Selegeline produced $\mathrm{K}_{\mathrm{i}}$ value $(\mu \mathrm{M})$ of $1.35 \pm 0.12$.

Rahman et al. have synthesized 2pyrazoline derivatives possessing selective MAO-B inhibition property [23]. The compound $\mathbf{1 0}$ was found to be the most potent with $\mathrm{IC}_{50}(\mu \mathrm{M})$ for MAO-B of
$40.78 \pm 3.66$ while that of Selegeline is $2.01 \pm 0.15$.

Anti-depressant property of a new series of synthesized pyrazoline derivatives attached to quinazolinone ring was evaluated. Kelekci et al prepared this series of pyrazolines derivatives [24]. According to the experiments performed, it was found that the derivative 11have $\mathrm{K}_{\mathrm{i}}$ value $(\mu \mathrm{M})$ $0.9 \pm 0.07$ (MAO-A) whereas the standard drug Clorgyline was found to have $1.20 \pm 0.09$ and $5.60 \pm 0.44$ for MAO-A and $\mathrm{B}$ respectively.

Ten new 3,5-diphenyl-2-pyrazoline derivatives were synthesized by reacting 1,3-diphenyl-2-propen-1-one with hydrazine hydrate by Palaska et al. and for the evaluation of the anti-depressant property, these compounds were subjected to the 'Porsolt Behavioral Despair Test' on Swiss-Webster mice [25]. 3-(4Methoxyphenyl)-5-(3,4-dimethoxyphenyl)2-pyrazoline; 3-(4-methoxyphenyl)-5-(2chloro-3,4-dimethoxyphenyl)-2-pyrazoline and 3-(4-chlorophenyl)-5-(2-chloro-3,4dimethoxyphenyl)-2-pyrazoline reduced $41.94-48.62 \%$ immobility times at 100 $\mathrm{mg} / \mathrm{kg}$ dose level. Along with that, it was found that 4-methoxy and 4-chloro substituents on the phenyl ring at position 3 of the pyrazoline ring maximized the antidepressant activity; the replacement of these groups by bromo and methyl substituents 
decreased activity in mice. The most potent was derivative 12 with duration of immobility time of $22.3 \pm 6.0$ seconds whereas the standard drug<smiles>CC(=O)N1N=C(c2ccccc2)CC1c1ccc(Cl)cc1</smiles>

6a<smiles>CC(=O)N1N=C(c2ccc(F)cc2)CC1c1ccc(F)cc1</smiles>

6b<smiles>COc1ccc(C2CC(c3ccccc3O)=NN2C(=S)Nc2ccccc2)cc1</smiles>

7

$\mathrm{HO}$<smiles>Cc1ccc(C2=NN(C(=S)Nc3cccc(C)c3)C(c3cccs3)C2)cc1</smiles>

8<smiles>COc1ccc(NC(=S)N2N=C(c3ccccc3O)CC2c2ccccc2O)cc1</smiles>

10<smiles>NC(=S)N1N=C2CCCCC2C1c1ccco1</smiles>

9a<smiles>NC(=S)N1N=C2CCCCC2C1c1cccs1</smiles>

9b<smiles>COc1ccc(C2=NNC(c3ccc(OC)c(OC)c3Cl)C2)cc1</smiles>

12<smiles>Cn1c(N2N=C(C3=CC(Cl)=CC3)CC2c2ccccc2)nc2ccccc2c1=O</smiles>

11<smiles>CCNC(=O)N1N=C(c2ccco2)CC1c1ccccc1</smiles>

13 
Ozdemir et al synthesized twelve 1-phenyl-

, 1-thiocarbamoyl- and 1-N-substituted thiocarbamoyl-3-(2-furyl)-5-phenyl/(2furyl)-2-pyrazoline derivatives [26]. The nonselective MAO inhibitory activity of the compounds were investigated by Porsolt behavioral despair (forced swimming) test on albino mice and the potent compound with duration of immobility time of $139 \pm 12$ seconds found was $\mathbf{1 3}$ and the standard drug Tranylcypromine sulfate $(10 \mathrm{mg} / \mathrm{kg}$, ip) with duration of immobility time of $57 \pm 11.6$ seconds.

Five new 1, 3, 5-triphenyl-2pyrazolines were synthesized by reacting 1 , 3-diphenyl-2-propene-1-one with phenyl hydrazine hydrochloride and another five new 3-(2"-hydroxynaphthalen-1"-yl)-1,5diphenyl-2-pyrazolines were synthesized by reacting 1-(2'-hydroxynaphthyl)-3phenyl-2-propene-1-one with phenyl hydrazine hydrochloride. Prasad et al performed this experiment [27]. The antidepressant activity (MAO inhibition) of these compounds was evaluated by the Porsolt behavioral despair test on SwissWebster mice. 1-Phenyl-3-(2"hydroxyphenyl)-5-(4'-dimethylaminophenyl)-2 pyrazolines; 5-(4'-dimethylaminophenyl)-1,3diphenyl-2-pyrazoline, 1-phenyl-3-(2'hydroxynaphthalen-1"-yl)-5-3',4',5'trimethoxyphenyl)-2-pyrazoline; 1-phenyl-3(4"-methylphenyl)-5-(4'dimethylaminophenyl)-2-pyrazoline and 1- phenyl-3-(4"-bromophenyl)-5-(4'-

dimethylaminophenyl)-2-pyrazoline reduced time of immobility by $25.63-59.25 \%$ at 100 $\mathrm{mg} / \mathrm{kg}$ dose level. The most potent derivative $\mathbf{1 4}$ has duration of immobility time of $22.95 \pm 4.21$ seconds against the standard drug Clomipramine $(20 \mathrm{mg} / \mathrm{kg}$ ) has immobility time of $18.68 \pm 2.25$ seconds.

Twelve 1-N-substituted thiocarbamoyl-3phenyl-5-thienyl-2-pyrazoline derivatives were synthesized by Ucar et al. which were presented as selective and irreversible MAO-B inhibitors [28]. The experimental data suggested that newly synthesized $N$ substituted pyrazoline derivatives can be evaluated as both MAO-B and cholinesterase inhibitors which may have promising activity in the treatment of Alzheimer's and Parkinson's diseases. The main derivative 15 hasIC $_{50}(\mu \mathrm{M}) 22.0 \pm 0.91$ and the standard drug Pargyline has $\mathrm{IC}_{50}$ $(\mu \mathrm{M})$ of $2.8 \pm 0.80$.

3,5-Diaryl pyrazolines analogs were synthesized and evaluated by Mishra et al. for their MAO inhibitory activity [29]. The compounds were found to have reversible and selective inhibitory effect towards MAO-B with selectivity index of $10^{3}-10^{5}$. The main derivative 16 with $K_{i}$ value $(\mu \mathrm{M})$ 0.33 proved to be the most potent form.

Linezolid, due its MAO inhibitory activity, was subjected to synthesis of its derivatives and evaluation for their MAO- 
inhibitory activity. Thirty-two compounds analyzed by Jayaprakash et al.showed selective to nonselective, competitive, reversible to non-competitive, irreversible inhibitory activity against two isoforms of rat liver MAO-A and MAO-B [30]. The potent derivative $\mathbf{1 7}$ hasIC $_{50}$ for MAO-A $(\mu \mathrm{M}) \quad 2.84 \pm 0.19$ and the standard drug Clorgyline has $\mathrm{IC}_{50}$ for MAO-A $(\mu \mathrm{M})$ $2.05 \pm 0.19$.

Ten novel 3,5-diaryl pyrazolines were synthesized and investigated by Sahoo et al. for their MAO inhibitory property [31]. All the molecules were found to be reversible and selective inhibitor for either one of the isoform (MAO-A or MAO-B) but the derivatives 18a and 18b having $K_{i} \quad \operatorname{value}(\mu \mathrm{M})$ 0.16(MAO-A) and 0.54(MAO-B) were found to be most potent derivatives.

Jagrat et al synthesized and analyzed twenty-two pyrazoline derivatives for their human MAO-A inhibitory activity [32]. The derivative 19 provedto have maximum potency with $\mathrm{K}_{\mathrm{i}}$ value $(\mu \mathrm{M}) \quad 0.1 \pm 0.01$ whereas the standard drug Selegeline has $\mathrm{K}_{\mathrm{i}}$ value $(\mu \mathrm{M}) 9.060 \pm 4.40$.

Some differently substituted 3-aryl-4,5dihydropyrazoles-1-carbothioamides have been synthesized by Maccioni et al with the aim to investigate their MAO inhibitory activity [33]. The potent derivatives 20a and 20b have $\mathrm{IC}_{50} \quad 13.70 \pm 0.95$ and
$15.47 \pm 0.61$ and the standard drug Clorgyline has $\mathrm{IC}_{50}(\mu \mathrm{M})$ of $61.35 \pm 13$.

A novel series of 1-acetyl-3,5-diphenyl-4,5dihydro-( $(1 H)$-pyrazole derivatives have been synthesized by Manna et al through the process of condensation and investigated for the ability to inhibit selectivity monoamine oxidase and found that the most potent derivative $\mathbf{2 1}$ had $\mathrm{K}_{i}$ value of $8.0 * 10^{-4} \pm 0.09$ where 0.09 is standard deviation [34].

Kelekci et al synthesized a novel series of 1-thiocarbamoyl-3-substituted phenyl-5-(2pyrrolyl)-4,5-dihydro-( $1 H)$-pyrazole

derivatives and came to the conclusion that the derivative $\mathbf{2 2}$ was the most potent form as promising MAO-A inhibitor with $\mathrm{IC}_{50}$ of $11.23 \pm 1.06 \mu \mathrm{M}$ with respect to the standard drug Clorgyline $\mathrm{IC}_{50}$ of $2.72 \pm 0.98 \mu \mathrm{M}$ [35].

New substituted pyrazole derivatives were designed and synthesized by Aziz et al and evaluated its antidepressant property and found that the derivative $\mathbf{2 3}$ was most potent with duration of immobility time of $198.70 \pm 6.80$ seconds with respect to the standard drug imipramine having duration of immobility time of $132.00 \pm 2.60$ seconds [36].

A novel series of crude 1-acetyl-3(4-hydroxy- and 2,4-dihydrophenyl)-5phenyl-4,5-dihydro- $(1 H) \quad$ pyrazole derivatives have been synthesized by Chimenti et al from chalcones and 
investigated for their MAO (monoamine oxidase) inhibitory activity and they were found to have both MAO-A and B inhibitory activity. The most potent derivatives $24 \mathbf{a}$ and $\mathbf{2 4 b}$ had $\mathrm{IC}_{50}$ of $1.0 *$ $10^{-8} \pm 0.01 \mu \mathrm{M}$ and $1.0 * 10^{-4} \pm 0.06 \mu \mathrm{M}$ for MAO-A and MAO-B respectively [37].

A new series of N1-thiocarbamoyl-3,5di(hetero)aryl-4,5-dihydro-(1H)-pyrazole derivatives has been synthesized by Chimenti et al by Claisen-Schimdt

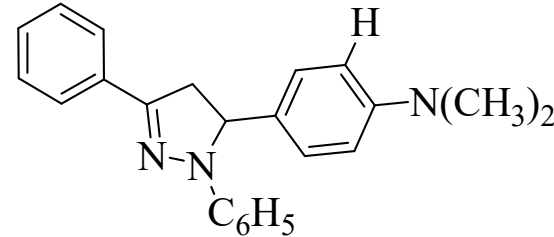

14<smiles>O=[N+]([O-])c1cccc(C2CC(c3c4ccccc4cc4ccccc34)=NN2)c1</smiles>

16 condensation at reflux between substituted aryl or heteroaryl ketones and appropriate substituted aryl or heteroaryl aldehydes and subjected them for the evaluation of their antidepressant property [38]. The conclusion thus obtained revealed that the derivative 25 proved be most potent with $\mathrm{IC}_{50}(\mathrm{MAO}-\mathrm{B})$ value of $2.75 \pm 0.81 \mu \mathrm{M}$ with respect to the standard drug Iproniazide having $\mathrm{IC}_{50}$ value of $7.54 \pm 0.36 \mu \mathrm{M}$.<smiles>CCNC(=S)N1N=C(c2ccc(OC)cc2)CC1c1cccs1</smiles><smiles>COc1ccc(C2=NN(C(=S)Nc3ccccc3)C(c3ccc(O)cc3)C2)cc1</smiles>

17<smiles>Oc1ccccc1C1=NNC(c2ccccc2O)C1</smiles>

$18 b$<smiles>NC(=S)N1N=C(c2ccccc2)CC1C1=CC=[SH]C=C1</smiles>

19 
<smiles>CNC(=S)N1CCC(c2ccc(OC)cc2)=N1</smiles>

20a<smiles>COc1ccc(C2=NN(C(N)=S)CC2)cc1</smiles>

20b<smiles>CC(=O)C1C=C(c2ccc(O)cc2O)CC1c1ccccc1C</smiles>

21<smiles>CC(=O)N1N=C(c2ccc(O)cc2)CC1c1cccc(Cl)c1</smiles>

24a

\section{CONCLUSION}

It has been found that the potency of the pyrazoline derivatives depend on the type of substitutions in the $3^{\text {rd }}$ and $5^{\text {th }}$ positions. Further the activity is boosted up by either thioacetamide or ketone substituents in the $1^{\text {st }}$ position. The substitutions in the $3^{\text {rd }}$ and $5^{\text {th }}$ position should be aromatic rings, substituted or non-substituted, but the potency has been observed to decrease if 5-membered aromatic rings such as thiophene of furan are placed instead of 6-membered substituted phenyl group. If $1^{\text {st }}$ position has thioacetamide and benzene \& $1 \lambda^{4}$ Thiopyran in the $3^{\text {rd }}$ and $5^{\text {th }}$ position respectively, the derivative was found to be<smiles>COc1ccccc1C1CC(c2ccc(C)cc2)=NN1C(C)=O</smiles>

24b<smiles>CCOC(=O)C1=NN(C(=O)c2cccs2)C(=O)C1C#N</smiles>

23

the most potent drug as MAO-A inhibitor. Again the $1^{\text {st }}$ position no substitution and fused phenyl ring in the $3^{\text {rd }}$ and $4^{\text {th }}$ position and furan in the $5^{\text {th }}$ position, potent activity is observed. Now, if thioacetamide in the $1^{\text {st }}$ position be substituted further with alkyl chain or phenyl group along with substituted phenyl groups in the $3^{\text {rd }}$ and $5^{\text {th }}$ position activity slightly decreases.

\section{CONFLICT OF INTEREST}

The authors declare no conflict of interest.

\section{REFERENCE}

[1] Dhingara D, Sharma A. A review on antidepressant plants. Natural Product Radiance 2006; 5(2): 144-152.

[2] Girish MB, Bhuvana K, Raju, GN, Sarala N. A novel atypical 
antidepressant drug: agomelatine - a review. Int J Pharm Biomed Res 2010; 1(3): 113-116.

[3] Malhotra S, Kaur N, Kumar P, Bhatia MS. Hans C. Viral infections and depression. Delhi Psych J 2012; 15(1): 188-195.

[4] Richards D, Richardson T. Computerbased psychological treatments for depression: a systemic review and meta-analysis. Clin Psychol Rev 2012; 32: 329-342.

[5] Schmidt PJ. Mood, depression, and reproductive hormones in the menopausal transition. Am J Med 2005; 118(12): 1407.

[6] McKenna WJ, Elliott Perry Inherited heart conditions Hypertrophic cardiomyopathy. British Heart Foundation 2009; M111C 0909.

[7] Gerardy J, Dresse A. Regional action of brofaromine on rat brain MAO-A and MAO-B. Prog. NeuroPsychopharmacol Biol Psychiat 1998; 22: 1141-1155.

[8] Singh H, Sattayasai J, Lattmann P, Boonprakob Y, Lattmann E. Antidepressant/anxiolytic and antinociceptive effects of novel 2substituted 1,4-benzodiazepine-2-ones. Scipharm. 2010; 78(2): 155-169.

[9] Kanagarajan V, Thanusu J, Gopalakrishnan M. Synthesis, spectral characterization, in-vitro antibacterial and antifungal activities of novel (2e)ethyl-2-(2-(2, 4-dinitrophenyl)

hydrazono)-4-(naphthalen-2-yl)-6-

arylcyclohex-3-enecarboxylates. Ir J Pharm Res .2011; 10(4): 711-725.

[10]Zuniga AC, Villareal NZ, Toscano RA. Crystal structure of 5-tbutoxycarbonyl-1-benzoyl-2pyrrolidone, an intermediate in the synthesis of (-)-rolipram. Jap Soc Anal Chem 2002; 18: 859-860.

[11] Manjula SN, Bharath EN, Divya B. Medicinal and biological significance of quinazoline: ahighly important scaffold for drug discovery: a review. Int J Pharm Bio Sc 2011; 2.

[12] Tomar A. Mall M. Verma M. Piperazine: the molecule of diverse pharmacological importance. Int J Res Ayur Pharm 2011; 2(5): 1547-1548.

[13] Siddiqui N. Bawa SA. Ali R. Afzal O. Akhtar MJ. Azad B. et al. Antidepressant potential of nitrogen containing heterocyclic moieties: an update review. J Pharm Bioal Sc 2011; 3(2): 194-212.

[14] Ozdemir Z. Kandilc HB. Gumusel B. Calis U. Bilgin AA. Synthesis and studies on antidepressant and anticonvulsant activities of some 3-(2thienyl) pyrazoline derivatives. Arch 
Pharm Chem Life Sci 2008; 341: 701 707.

[15] Kaplancikli ZA. Ozdemir A. Zitouni GT. Altintop MD. Can OD. New pyrazoline derivatives and their antidepressant activity. Eur J Med Chem 2010; 45: 4383-4387.

[16] Ruhoglu O. Ozdemira Z. Calis U. Gumuselb B. Bilgin A. A.Synthesis of and pharmacological studies on the antidepressant and anticonvulsant activities of some 1, 3, 5-trisubstituted pyrazolines. Arzneim.-Forsch Drug Res 2005; 55(8): 431-436.

[17] Iyidogan P. Ozdemir Z. Kandilci B. Gumusel B. Calis,U. Bilgin A A. Synthesis of some new 1, 3, 5trisubstituted pyrazolines with antidepressant and anticonvulsant activities. J Fac Pharm 2005; 38(1): 47-56.

[18]Fioravanti R. Bolasco A. Manna F. Rossi F. Orallo F. Yanez M. et al. Synthesis and molecular modeling studies of prenylated pyrazolines as MAO-B inhibitors. Bioorg Meld Chem Lett 2010; 20: 6479-6482.

[19] Chimenti F. Fioravanti R. Bolasco A. Manna F. Chimenti P. Secci D. et al. Synthesis, molecular modeling studies and selective inhibitory activity against MAO of N1-propanoyl-3, 5-diphenyl-
4, 5-dihydro-(1H)-pyrazole derivatives. Eur J Med Chem 2008; 43: 2262-2267.

[20] Jayaprakash V. Yabanoglu S. Sinha BN. Ucar G. Pyrazoline-based mycobactin analogues as dual inhibitors of $\mathrm{MAO} / \mathrm{Cholinesterase.}$ Turk J Biochem 2010; 35(2): 91-98.

[21]Karuppasamy M. Mahapatra M. Yabanoglu S. Ucar G. Sinha BN.; Basu Aet al. Development of selective and reversible pyrazoline based MAO-A inhibitors: synthesis, biological evaluation and docking studies. Bioorg Med Chem Lett 2010; 18: 1875-1881.

[22] Kelekci NG. Simsek OO. Ercan A. Yelekci K. Sahin ZS. Isik S. et al. Synthesis and molecular modeling of some novel hexahydroindazole derivatives as potent monoamine oxidase inhibitors. Bioorg Med Chem Lett 2009, 17: 6761-6772.

[23] Rahman MA. Siddiqui AA. Pyrazoline derivatives: a worthy insight into the recent advances and potential pharmacological activities. Int J Pharm Sci Res 2010; 2(3): 165-175.

[24] Kelekci NG. Koyunoglu S. Yabanoglu S. Yelekci K. Ozgen O. Ucar G. et al. A.New pyrazoline bearing $4(3 \mathrm{H})-$ quinazolinone inhibitors of monoamine oxidase: synthesis, biological evaluation, and structural determinants of MAO-A and MAO-B selectivity. 
Bioorg Med Chem Lett 2009; 17: 675689.

[25] Palaska E. Aytemira M. Uzbay IT. Erol D. Synthesis and antidepressant activities of some 3, 5-diphenyl-2pyrazolines.Eur J Med Chem. 2001; 36: 539-543.

[26] Ozdemir Z. Kandilci HB. Gumusel B. Calis U. Bilgin AA. Synthesis and studies on antidepressant and anticonvulsant activities of some 3-(2furyl)-pyrazoline derivatives. Eur J Med Chem.2007; 42: 373-379.

[27] Prasad Y.R. Rao AL. Prasoona L. Murali K. Kumar PR. Synthesis and antidepressant activity of some 1,3,5triphenyl-2-pyrazolines and 3-(2'"hydroxy naphthalen-1'"-yl)-1,5diphenyl-2-pyrazolines. Bioorg Med Chem Lett 2005; 15: 5030-5034.

[28] Ucar G. Gokhan N. Yesilada A.;Bilgin AA. 1-N-Substituted thiocarbamoyl-3phenyl-5-thienyl-2-pyrazolines: a novel cholinesterase and selective monoamine oxidase $\mathrm{B}$ inhibitors for the treatment of Parkinson's and Alzheimer's diseases. Neurosci Lett 2005; 382: 327-331.

[29] Mishra N. Sasmal D. Development of selective and reversible pyrazoline based MAO-B inhibitors: virtual screening, synthesis and biological evaluation. Bioorg Med Chem Lett 2011; 21: 1969-1973.

[30] Jayaprakash V. Sinha BN. Ucar G. Ercan A. Pyrazoline-based mycobactin analogues as MAO-inhibitors. Bioorg Med Chem Lett 2008; 18: 6362-6368.

[31] Sahoo A. Yabanoglu S. Sinha BN. Ucar G. Basu A. Jayaprakash V. Towards development of selective and reversible pyrazoline based MAOinhibitors: synthesis, biological evaluation and docking studies. Bioorg Med Chem Lett 2010; 20: 132-136.

[32] Jagrat M. Behera J. Yabanoglu S. Ercan A. Ucar G. Sinha B.N. et al. Pyrazoline based MAO inhibitors: synthesis, biological evaluation and SAR studies. Bioorg Med Chem Lett 2011; 21: 4296-4300.

[33] Maccioni E. Alcaro S. Orallo F. Cardia MC. Distinto S. Costa G. et al. Synthesis of new 3-aryl-4,5dihydropyrazole-1-carbothioamide derivatives. An investigation on their ability to inhibit monoamine oxidase. Eur J Med Chem 2010; 45: 4490-4498. [34]Manna F. Chimenti F. Bolasco A. Secci D. Bizzarri B. Befanio O. et al. A. Inhibition of amine oxidases activity by 1-acetyl-3,5-diphenyl-4,5dihydro-(1H)-pyrazole derivatives. Bioorg Med Chem Lett 2002; 12: 3629-3633. 
[35] Kelekci NG. Yabanoglu S. Kupeli E. Salgin U. Ozgen O. Ucar G. et al. A new therapeutic approach in Alzheimer disease: some novel pyrazole derivatives as dual MAO-B inhibitors and inflammatory analgesics. Bioorg Med Chem Lett 2007; 15: 5775-5786.

[36] Aziz MA. Rahma GEAA. Hasan AA. Synthesis of novel pyrazole derivatives and evaluation of their antidepressant and anticonvulsant activities. Eur J Med Chem 2009; 44: 3480-3487.

[37]Chimenti F. Bolasco A. Manna F. Secci D. Chimenti P. Befani O. et al. Synythesis and selective inhibitory activity of 1-acetyl-3,5-diphenyl-4,5dihydro-(1H)-pyrazole derivatives against monoamine oxidase. J Med Chem 2004; 47: 2071-2074.

[38] Chimenti F. Carradori S. Secci D. Bolasco A. Bizzarri B. Chimenti P. et al. Synthesis and inhibitory activity against human monoamine oxidase of N1-thiocarbamoyl-3,5-di(hetero)aryl4,5-dihydro-( $1 \mathrm{H})$-pyrazole derivatives. Eur J Med Chem 2010; 45: 800-804. 